Original Research Paper

\title{
Preliminary Evaluation of a Permeable Reactive Barrier for Reducing Groundwater Nitrate Transport from a Large Onsite Wastewater System
}

\author{
${ }^{1}$ Charles Humphrey, ${ }^{2}$ Sushama Pradhan, ${ }^{3}$ Eban Bean, ${ }^{4}$ Michael O'Driscoll and ${ }^{5}$ Guy Iverson \\ ${ }^{I}$ Department of Health Education and Promotion, East Carolina University, \\ 3408 Carol Belk Building, Greenville, NC 27858, USA \\ ${ }^{2}$ North Carolina Department of Health and Human Services, \\ 5605 Six Forks Road, Building 3, Raleigh, NC 27609, USA \\ ${ }^{3}$ Department of Engineering, Institute for Coastal Science and Policy, \\ East Carolina University, Slay 250, Greenville, NC 27858, USA \\ ${ }^{4}$ Department of Geological Sciences, East Carolina University, 204 Graham, Greenville, NC 27858, USA \\ ${ }^{5}$ Coastal Resources Management Program PhD Program, East Carolina University, USA
}

Article history

Received: 31-03-2015

Revised: 25-06-2015

Accepted: 18-08-2015

Corresponding Author:

Charles Humphrey

Department of Health Education

and Promotion, East Carolina

University, 3408 Carol Belk

Building, Greenville, NC 27858, USA

Email: Humphreyc@ecu.edu

\begin{abstract}
A permeable reactive barrier was installed between a large Onsite Wastewater System (OWS) and a monitoring well located downgradient from the OWS. Groundwater samples from the well had shown elevated and increasing concentrations of $\mathrm{NO}_{3}^{-}-\mathrm{N}\left(>20 \mathrm{mg} \mathrm{L}^{-1}\right.$ for 2 years). The barrier was constructed using woodchips from various tree species that were placed in a trench excavated to approximately the same depth as the well which was experiencing elevated $\mathrm{NO}_{3}{ }^{-}-\mathrm{N}$ concentrations. Groundwater samples (5) were collected from the well between two weeks and four months after the barrier was installed. Groundwater $\mathrm{NO}_{3}{ }^{-} \mathrm{N}$ concentrations dropped by an average of $5 \mathrm{mg} \mathrm{L}^{-1}$, while Dissolved Organic Carbon (DOC) concentrations increased by 11 $\mathrm{mg} \mathrm{L} \mathrm{L}^{-1}$ and $\mathrm{Cl}$ concentrations stayed relatively stable $\left(<2 \mathrm{mg} \mathrm{L^{-1 }}\right.$ increase). The data suggest that denitrification fueled by the DOC from the barrier may be contributing to the lower $\mathrm{NO}_{3}{ }^{-} \mathrm{N}$ concentrations. Monitoring will continue at the site to determine the longer-term water quality trends. More research should be conducted to evaluate the applicability of permeable barriers as a best management practice for non-point sources of pollution in nutrient sensitive areas.
\end{abstract}

Keywords: Nitrogen, Onsite, Wastewater, Permeable Barrier

\section{Introduction}

\section{Onsite Wastewater Treatment Systems and Nitrogen}

Onsite Wastewater treatment Systems (OWS) are used in locations where centralized sewer service is not available. Over $23 \%$ of residences in the United States and almost $50 \%$ of residences in North Carolina use OWS (USEPA, 2002; Pradhan et al., 2007). Wastewater Total Dissolved Nitrogen (TDN) entering the septic tank is mostly Organic Nitrogen (ON) and ammonium nitrogen $\left(\mathrm{NH}_{4}{ }^{+} \mathrm{N}\right)$, with very low concentrations of nitrate nitrogen $\left(\mathrm{NO}_{3}^{-}-\mathrm{N}\right)$ (Lowe et al., 2007). The organic nitrogen is typically mineralized to $\mathrm{NH}_{4}{ }^{+}-\mathrm{N}$ in the septic tank, thus septic tank effluent is typically $75 \%$ or more $\mathrm{NH}_{4}{ }^{+}-\mathrm{N}$ (Cardona, 2006). Effluent rich in $\mathrm{NH}_{4}{ }^{+}$ $\mathrm{N}$ may be converted to $\mathrm{NO}_{3}^{-}-\mathrm{N}$ in aerated soil beneath the drainfield trenches via the nitrification process (Humphrey et al., 2010), thus drainfield trenches are often referred to as nitrification trenches. Nitrate is an anion and is susceptible to leaching through soils, resulting in elevated groundwater $\mathrm{NO}_{3}-\mathrm{N}$ concentrations beneath and down-gradient from OWS. For example, $\mathrm{NO}_{3}-\mathrm{N}$ concentrations exceeding $20 \quad \mathrm{mg} \mathrm{L} \mathrm{L}^{-1}$ in groundwater beneath and/or adjacent to septic systems have been reported for the Coastal Plain of North Carolina (Buetow, 2002; Humphrey et al., 2010; 2013; 
O'Driscoll et al., 2014), a sandy aquifer in Ontario, Canada (Harman et al., 1996), a coastal barrier bar in Point Pelee, Ontario, Canada (Ptacek, 1998), in Rhode Island (Postma et al., 1992) and in the Coastal Plain of Virginia (Reay, 2004). Furthermore, studies by Harman et al. (1996), Robertson et al. (1991) and Ptacek (1998) in Canada, Buetow (2002), Humphrey et al. (2013) and O'Driscoll et al. (2014) in the Coastal Plain of North Carolina and Reay (2004) in Coastal Virginia, reported groundwater $\mathrm{NO}_{3}^{-}-\mathrm{N}$ concentrations exceeding $10 \mathrm{mg} \mathrm{L}^{-1}$ more than $15 \mathrm{~m}$ down-gradient from the systems. Water supplies with $\mathrm{NO}_{3}^{-}-\mathrm{N}$ concentrations greater than $10 \mathrm{mg} \mathrm{L}^{-1}$ may be hazardous to infants and pregnant women due to methemoglobinemia, or blue baby syndrome (Brady and Weil, 2003). Therefore, the US Environmental Protection Agency maximum contaminant level for $\mathrm{NO}_{3}^{-}-\mathrm{N}$ is set at $10 \mathrm{mg} \mathrm{L}^{-1}$ for drinking water sources/supplies. Surface water $\mathrm{NO}_{3}{ }^{-}-\mathrm{N}$ concentrations of $1 \mathrm{mg} \mathrm{L}^{-1}$ or potentially less may lead to increased algal production, eutrophication, lowering of dissolved oxygen concentrations and potential fish kills (NOAA, 1996). Massive fish kills in Albemarle Pamlico Estuary, particularly near the mouths of the Neuse and Tar Rivers in North Carolina have been attributed to excess nitrogen and phosphorus loadings (Osmond et al., 2003). Therefore, elevated $\mathrm{NO}_{3}^{-}-\mathrm{N}$ concentrations in groundwater and surface waters are a major environmental issue.

\section{Onsite Wastewater Systems and Permeable Reactive Barriers}

OWS are typically installed in aerobic soil environments that are favorable for nitrification (conversion of $\mathrm{NH}_{4}$ to $\mathrm{NO}_{3}$ ) to occur. Nitrate is mobile in groundwater and may discharge to surface waters contributing to increased nutrient loads and exacerbating eutrophic conditions (Bowen and Valiela, 2004). Denitrification (conversion of $\mathrm{NO}_{3}$ to $\mathrm{N}_{2}$ ) is a process for $\mathrm{NO}_{3}$ removal from groundwater and generally requires anaerobic conditions, $\mathrm{NO}_{3}$, a carbon source and denitrifying microorganisms (Desimone and Howes, 1996). Denitrification in soil and/or groundwater beneath OWS is often limited by the lack of an available carbon source which functions as the electron donor (Robertson et al., 1991; Del Rosario et al., 2014). While septic tank effluent is typically enriched with carbon, the carbon is oxidized to $\mathrm{CO}_{2}$ while $\mathrm{NH}_{4}{ }^{+}-\mathrm{N}$ is oxidized to $\mathrm{NO}_{3}{ }^{-}-\mathrm{N}$ in aerobic soils beneath the trenches. So groundwater becomes enriched in $\mathrm{NO}_{3}^{-}-\mathrm{N}$, but carbon escapes as a gas.

Research in Canada and New Zealand has shown that permeable reactive barriers or PRBs (trenches excavated to depths below the water table and filled with woodchips, saw dust or other carbon sources (Fig. 1)) can greatly reduce groundwater $\mathrm{NO}_{3}$ concentrations in contaminant plumes via denitrification (Robertson and Cherry, 1995; Schipper and Vojvodic-Vukovic, 2001; Long et al., 2011). Furthermore, Schipper and Vojvodic-Vukovic (2001) demonstrated that the PRB treatment efficiency of $\mathrm{NO}_{3}{ }^{-} \mathrm{N}$ was $95 \%$ for after 5-years of operation. Long et al. (2011) reported a $92 \% \mathrm{NO}_{3}{ }^{-}-\mathrm{N}$ reduction efficiency for a 14 year old PRB installed to intercept groundwater impacted by spray irrigation from a dairy in New Zealand. Therefore, PRBs can be efficient treatment units for many years after installation.

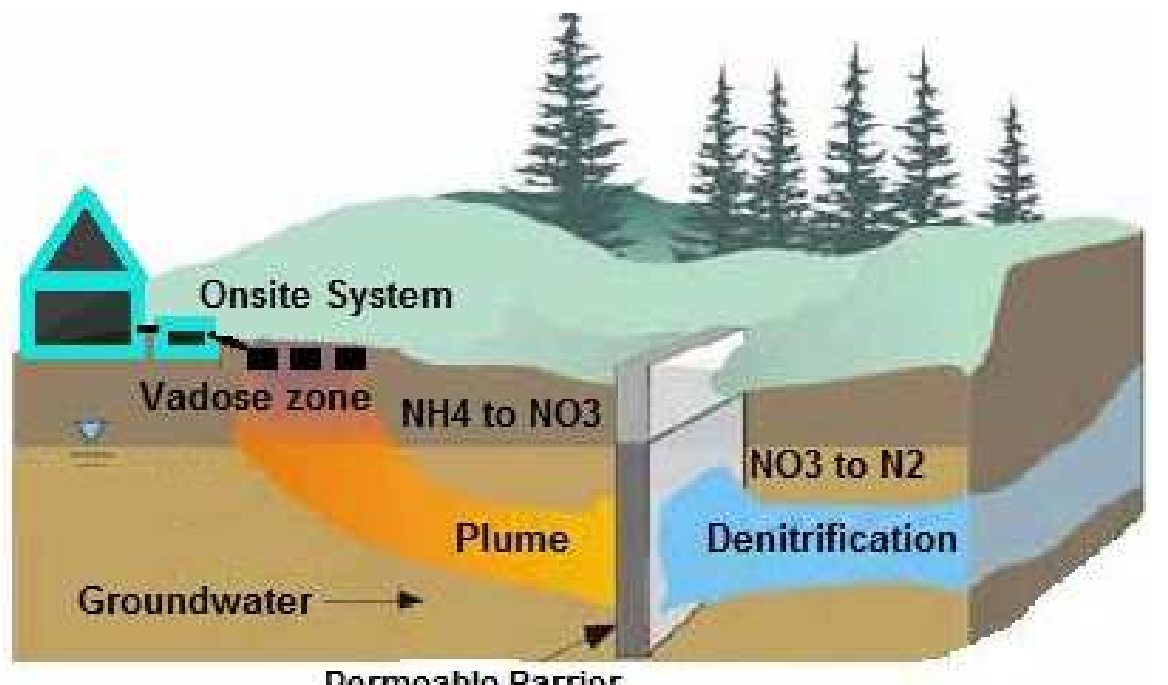

Fig. 1. Permeable reactive barrier installed within the groundwater flow path of a $\mathrm{NO}_{3}{ }^{-}-\mathrm{N}$ enriched plume from an onsite wastewater treatment system. $\mathrm{NH}_{4}{ }^{+}$is converted to $\mathrm{NO}_{3}{ }^{-}$in aerated soil beneath the drainfield trenches and the $\mathrm{NO}_{3}{ }^{-}$is converted to $\mathrm{N}_{2}$ gas as the plume migrates through the carbon-rich permeable barrier (PASS, 2015) 


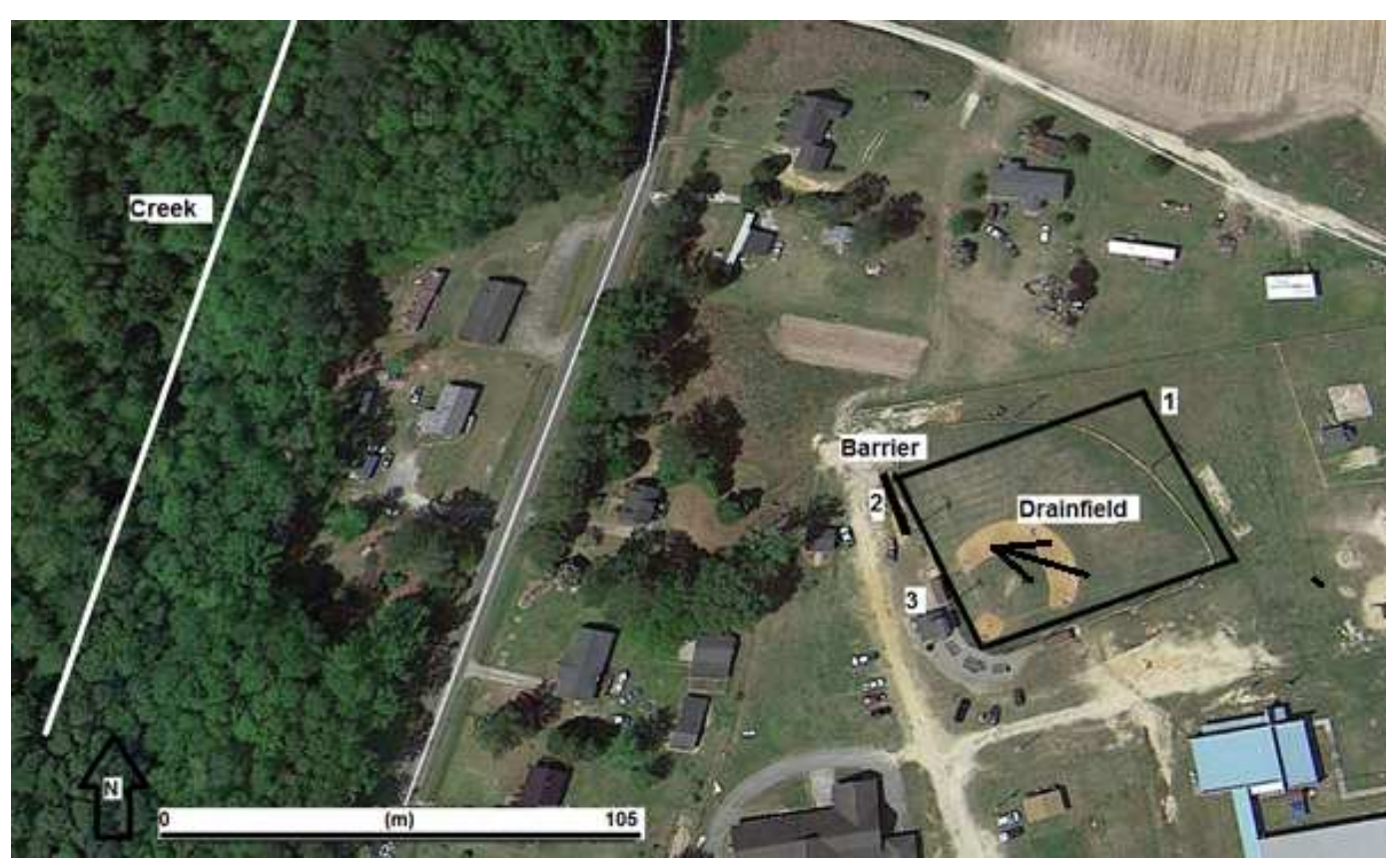

Fig. 2. Study site Martin County, NC. The school's onsite wastewater system drainfield area is shown in the square. Monitoring Wells 1-3 are shown in white boxes. Groundwater flow direction is NW as indicated by the arrow, so Well 1 is up-gradient from the system and Wells 2-3 are down-gradient from the system. The barrier is shown between Well 2 and the drainfield

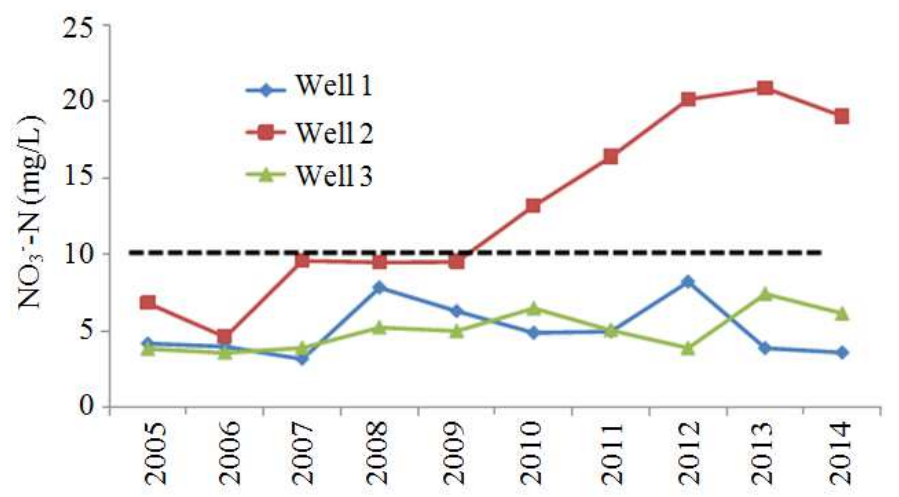

Fig. 3. Groundwater $\mathrm{NO}_{3}^{-}-\mathrm{N}$ concentrations in Wells 1,2 and 3 at the study site. The dashed line shows the state $\mathrm{NO}_{3}^{-}-\mathrm{N}^{-}$standard of $10 \mathrm{mg} \mathrm{L}^{-1}$. Well $2 \mathrm{NO}_{3}^{-}-\mathrm{N}$ concentrations have steadily increased since sampling started in 2005

\section{Study Site}

The study site was an elementary school in Martin County, NC that typically enrolls between 280 and 350 students. Wastewater generated at the school is managed via a large OWS. The OWS includes septic and pump tanks, a pressure manifold for effluent distribution and at least 9 drainfield trenches that are 64 min length. The drainfield trenches are located underneath a baseball field on the School's property. The OWS was installed in 2004. Three groundwater monitoring wells were installed near the OWS drainfield, with one well upgradient (Well 1) and two wells down-gradient (Well 2 and Well 3) from the OWS (Fig. 2).
Groundwater monitoring near the OWS began in 2005. Samples were typically collected 3 times per year from the wells and analyzed for $\mathrm{NO}_{3}{ }^{-} \mathrm{N}$, fecal coli form and solids content for comparison to State water quality standards. Groundwater quality was initially met for all tested parameters, however the $\mathrm{NO}_{3}{ }^{-} \mathrm{N}$ concentrations in groundwater collected from Well 2 have steadily increased since monitoring was initiated in 2005 (Fig. 3). Groundwater $\mathrm{NO}_{3}^{-}-\mathrm{N}$ standards are set at $10 \mathrm{mg} \mathrm{L}^{-1}$ and this threshold was first exceeded in Well 2 on the July 30, 2008 sampling event. The next two successive groundwater sampling events occurred in December 2008 (5.87 $\mathrm{mg} \mathrm{L}^{-1}$ ) and April 2009 (6.46 mg L${ }^{-1}$ ) and 
both were below $10 \mathrm{mg} \mathrm{L}^{-1}$. However, the August 2009 sample from Well $2\left(11.24 \mathrm{mg} \mathrm{L}^{-1}\right)$ exceeded the standard and every sample collected from Well 2 since August 2009 has been above the $10 \mathrm{mg} \mathrm{L}^{-1}$ threshold. The objectives of this study were to install a permeable reactive barrier down-gradient from a large OWS and determine if the barrier was successful in reducing groundwater $\mathrm{NO}_{3}^{-}-\mathrm{N}$ and TDN concentrations.

\section{Methods}

\section{Barrier Installation}

A trench with approximate dimensions of $1.2 \mathrm{~m}$ wide x $8 \mathrm{~m}$ deep x $6 \mathrm{~m}$ long was installed with an excavator on May 7, 2014. The trench was excavated just up-slope of Well 2, the well with elevated $\mathrm{NO}_{3}{ }^{-} \mathrm{N}$ concentrations (Fig. 2). Once groundwater was encountered at approximately $5.8 \mathrm{~m}$ beneath the surface, several more bucket loads of soil were excavated and then woodchips were dumped into the trench (Fig. 4). The woodchips used for this barrier were a mixture of different size chips from different tree species (although mostly Pinus Taeda). The woodchips came from a local lumber mill. Soil from the trench excavation was placed over the woodchips to partially enclose and stabilize that section of the barrier and then the next section of the trench was excavated. This process was repeated until the trench and barrier extended across both up-gradient sides of Well 2, perpendicular to the groundwater flow direction. The trench was then filled with the excavated soil to the pre-trench elevation.

\section{Groundwater and Onsite System Monitoring}

Depth to groundwater was determined at each well using a Solinst TLC meter. Each well was purged using a disposable bailer and groundwater was transferred from the bailer to Nalgene samples bottles and field meter cups. The sample bottles were labeled and placed in a cooler with ice for transport to the lab. An YSI 556 multimeter was used to determine groundwater $\mathrm{pH}$, Electrical Conductivity (EC), Dissolved Oxygen (DO), temperature and Oxidation Reduction Potential (ORP) in the field. The YSI was calibrated one day prior to each field sampling event.

Water samples were collected from the Wells 1-3 on May 6, 2014, one day prior to the barrier installation. The samples were sent to Environment 1 laboratory in Greenville, $\mathrm{NC}$ for $\mathrm{NO}_{3}{ }^{-}-\mathrm{N}$ analysis. This was a routine sampling event for the school and Environment 1 is the laboratory they have used historically. After the barrier installation, groundwater samples from Wells 1-3 were collected on 5 occasions including May 22, June 5, 17, 24, 2014 and September 3, 2014. The samples were filtered and analyzed for $\mathrm{NO}_{3}{ }^{-} \mathrm{N}, \mathrm{NH}_{4}{ }^{+} \mathrm{N}, \mathrm{TDN}$,
Dissolved Organic Carbon (DOC) and $\mathrm{Cl}$ at the East Carolina University Environmental Research Laboratory during May and June and at Environment 1 on September 3, 2014. The $\mathrm{NO}_{3}{ }^{-} \mathrm{N}, \mathrm{NH}_{4}{ }^{+}-\mathrm{N}$ and $\mathrm{Cl}$ analysis were performed using a Smart Chem 200 at East Carolina University. The TDN and DOC analysis were performed using a Shimadzu TOC-VCPN/TNM-1 and the combustion catalytic oxidation method and chemiluminescence detector. Pump tank effluent samples were collected and analyzed for the same constituents on these same dates; except for June 17 (lock would not open on pump tank). Water samples from an unnamed tributary of the Roanoke River approximately $170 \mathrm{~m}$ down-gradient from the OWS were also evaluated on site for the environmental parameters including $\mathrm{pH}, \mathrm{DO}, \mathrm{EC}, \mathrm{ORP}$ and temperature using the YSI 556 meter and for $\mathrm{NO}_{3}^{-}-\mathrm{N}$ using an YSI Pro-Plus. The tributary will be referred to as "creek" from this point forward in the manuscript.

\section{Groundwater Nitrogen Trends and Permeable Barrier Performance}

Groundwater $\mathrm{NO}_{3}{ }^{-}-\mathrm{N}$ data from Wells 1-3 from 2005 to May 6, 2014 were provided by the NC Department of Health and Human Services. Well data were plotted on graphs and regression and correlation analysis were used to determine if there were significant trends in $\mathrm{NO}_{3}{ }^{-} \mathrm{N}$ concentrations from 2005 to May 6, 2014 (before barrier installation). Groundwater $\mathrm{NO}_{3}{ }^{-} \mathrm{N}$ concentrations postbarrier were compared to the pre-barrier concentration trends and to the May 6, 2014 data (one day prior to barrier installation) to determine if the barrier was influencing groundwater $\mathrm{NO}_{3}{ }^{-} \mathrm{N}$ concentrations. Groundwater $\mathrm{Cl}$ concentrations were evaluated in relation to $\mathrm{NO}_{3}^{-}-\mathrm{N}$ concentrations to determine if potential changes in $\mathrm{NO}_{3}^{-}-\mathrm{N}$ were related to dilution. If both $\mathrm{Cl}$ and $\mathrm{NO}_{3}^{-}-\mathrm{N}$ decrease, then dilution is a potential dominant mechanism (Desimone and Howes, 2006; Del Rosario et al., 2014). If $\mathrm{NO}_{3}{ }^{-}-\mathrm{N}$ concentrations decrease but $\mathrm{Cl}$ concentrations remain stable or increase, then denitrification may be occurring (Desimone and Howes, 2006). Groundwater DOC concentrations in the Wells were graphed to determine if noticeable changes occurred in DOC concentrations in Well 2 after the barrier was installed and in comparison to Well 1 and Well 3. If groundwater moves through the woodchip barrier, then DOC concentrations may increase in Well 2 (down-gradient of barrier) relative to Well 1 and Well 3 (not down-gradient of the barrier). The Well $2 \mathrm{NO}_{3}^{-}-\mathrm{N}, \mathrm{Cl}$ and DOC data were compared to Well 1 and Well 3 to help determine if potential changes in groundwater chemistry after the barrier was installed were related to the barrier (changes in Well 2 only) or some other natural processes (all wells show no changes or similar changes). 


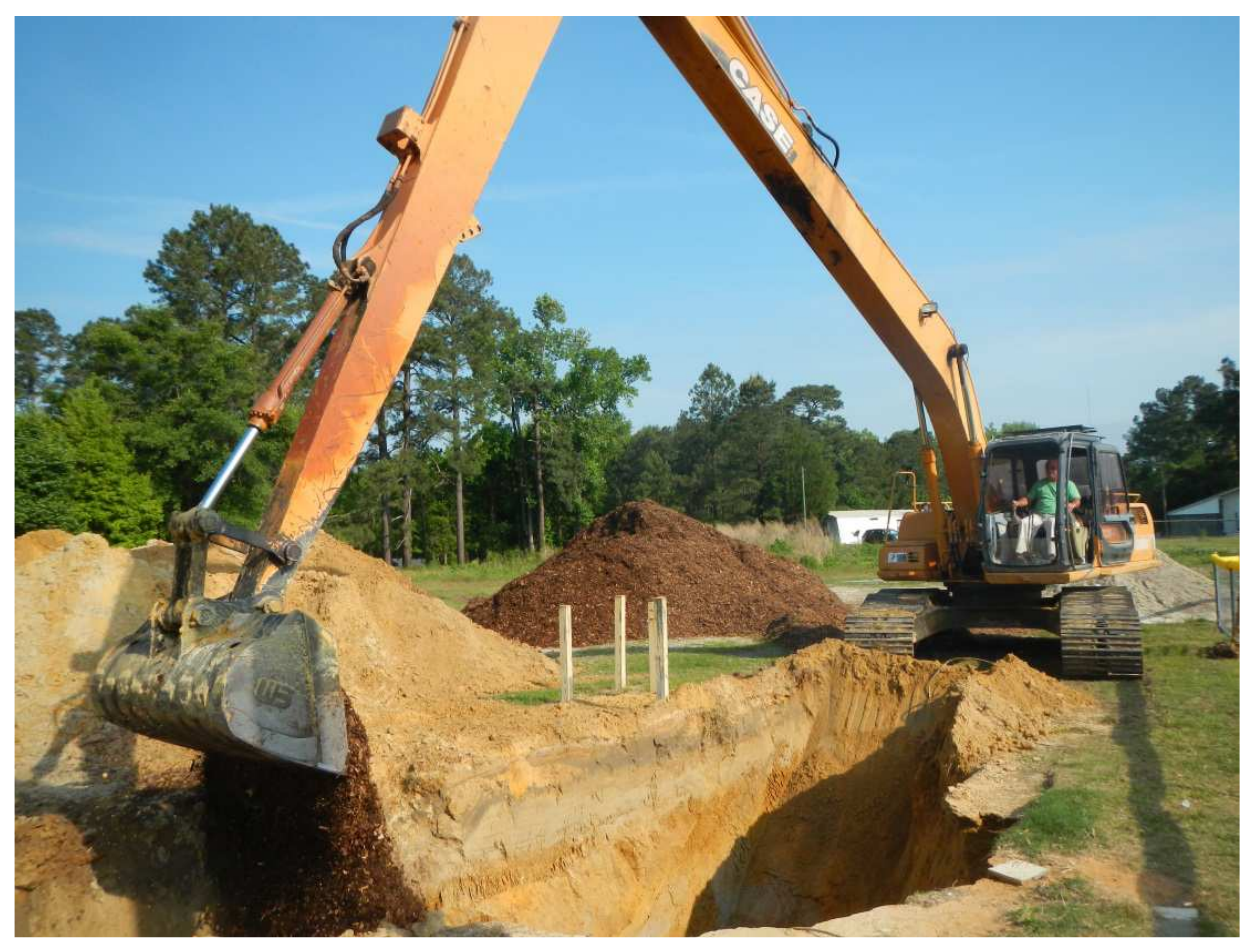

Fig. 4. Trench installation up-gradient from Well \#2. Woodchips are in a pile to left of the excavator

Pump tank effluent TDN concentrations were compared to groundwater TDN concentrations in Well 2 to determine the concentration reduction efficiency of the OWS. The average groundwater TDN concentrations of Well 2 were also compared to Well 3 and Well 1.

\section{Results and Discussion}

\section{Groundwater Nitrogen Trends Prior to Barrier Installation}

Groundwater $\mathrm{NO}_{3}^{-}-\mathrm{N}$ concentrations from Well 2 showed a steady increase since the initiation of routine sampling in 2005. Regression analysis indicated a strong relationship between Well 2 groundwater $\mathrm{NO}_{3}^{-}-\mathrm{N}$ concentrations (annual average) and years after the start of the sampling $\left(\mathrm{R}^{2}=0.89\right)$ (Fig. 5). The $\mathrm{NO}_{3}{ }^{-} \mathrm{N}$ concentration in groundwater from Well 2 has increased an average of $1.8 \mathrm{mg} \mathrm{L}^{-1}$ each year since 2006 and the yearly average $\mathrm{NO}_{3}{ }^{-} \mathrm{N}$ concentrations exceeded $20 \mathrm{mg} \mathrm{L}^{-1}$ in 2012 and 2013 (Fig. 3). There was a strong, positive correlation between years since the sampling was initiated and groundwater $\mathrm{NO}_{3}{ }^{-} \mathrm{N}$ concentrations at well $2(\mathrm{r}=0.947 ; \mathrm{p}=0.000)$. In contrast, the groundwater $\mathrm{NO}_{3}{ }^{-}-\mathrm{N}$ concentrations from Well 1 were not strongly associated with years after sampling started $\left(\mathrm{R}^{2}=0.0089\right)$ and there was not a significant correlation between $\mathrm{NO}_{3}{ }^{-}-\mathrm{N}$ concentrations and time after sampling started $(\mathrm{r}=0.094 ; p=0.796)$ (Fig. 5). Well 1 is located up-gradient from the OWS
(Fig. 2). Groundwater $\mathrm{NO}_{3}{ }^{-}-\mathrm{N}$ concentrations from Well 3 showed a moderate relationship with years after sampling $\left(\mathrm{R}^{2}=0.47\right)$ (Fig. 5). There was a moderate $(\mathrm{r}$ $=0.685)$ but significant $(p=0.029)$ correlation between the $\mathrm{NO}_{3}{ }^{-} \mathrm{N}$ concentrations and years after sampling was initiated. These data indicate that groundwater downgradient from the OWS was becoming more enriched with $\mathrm{NO}_{3}{ }^{-}-\mathrm{N}$ over time, especially near Well 2.

\section{Groundwater Nitrogen Trends after Barrier Installation}

The groundwater samples collected from Well 2 on May 6, 2014, the day prior to the PRB installation, had a

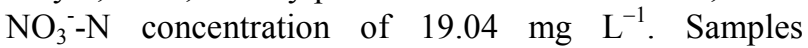
collected on May 22, June 5, 17, 24 and September 3, 2014 after the installation each had $\mathrm{NO}_{3}{ }^{-}-\mathrm{N}$ concentrations lower (range of 12.2 to $15.95 \mathrm{mg} \mathrm{L}^{-1}$ ) than pre-barrier installation concentrations. On the last sampling date of September 3, groundwater $\mathrm{NO}_{3}{ }^{-} \mathrm{N}$ concentrations from Well 2 were $6.84 \mathrm{mg} \mathrm{L}^{-1}$ or $36 \%$ lower than on May 6, 2014 the day prior to the PRB installation and the lowest measured concentrations since 2006. Groundwater $\mathrm{NO}_{3}{ }^{-} \mathrm{N}$ concentrations for Well 1 and Well 3 were also lower after the installation of the barrier, but the differences were not as large (Well 1 difference: $0.13 \mathrm{mg} \mathrm{L}^{-1}$; Well 3 difference: $0.29 \mathrm{mg} \mathrm{L}^{-1}$ ) (Fig. 6). When comparing groundwater $\mathrm{Cl}$ concentrations in the Wells after the barrier installation there was a slight increase for Well $2\left(+1.97 \mathrm{mg} \mathrm{L}^{-1}\right)$ and 
Well $3\left(+2.79 \mathrm{mg} \mathrm{L}^{-1}\right)$ and a slight decrease for Well 1 (0.95 mg L ${ }^{-1}$ ) (Fig. 6). Had the $\mathrm{NO}_{3}^{-}-\mathrm{N}$ concentration reductions for Well 2 been due to dilution alone, then $\mathrm{Cl}$ concentrations should have also been reduced during that time frame. A reduction in groundwater $\mathrm{NO}_{3}{ }^{-} \mathrm{N}$ concentration coupled with no change or a slight increase in groundwater $\mathrm{Cl}$ concentration may indicate that the $\mathrm{NO}_{3}{ }^{-}-\mathrm{N}$ reductions were not because of dilution, but some other mechanism such as denitrification. Wastewater typically has elevated concentrations of $\mathrm{Cl}$ relative to most groundwater (Humphrey et al., 2013; Del Rosario et al., 2014). At the study site, the average $\mathrm{Cl}$ concentration of wastewater was $158 \mathrm{mg} \mathrm{L}^{-1}$ and groundwater up-gradient from the OWS had average $\mathrm{Cl}$ concentrations of less than $5 \mathrm{mg} \mathrm{L}^{-1}$ (Table 1). Therefore, if the wastewater plume mixes with more groundwater (or infiltrating rainwater), then both $\mathrm{NO}_{3}{ }^{-} \mathrm{N}$ and $\mathrm{Cl}$ concentrations would be expected to decline in the plume because of dilution. This did not occur at Well 2. Groundwater DOC concentrations from Well 2 increased from $16.2 \mathrm{mg} \mathrm{L}^{-1}$ on May 22 to $27.48 \mathrm{mg} \mathrm{L}^{-1}$ on June 24 (Fig. 7), possibly because of DOC leaching from the woodchip barrier. The DOC concentrations were stable over this same time frame for Well 1 and initially dropped for Well 3, but were then stable (Fig. 7). While Well 2 and Well 3 were both down-gradient from the OWS, Well 2 was located $26.8 \mathrm{~m}$ north of Well 3 (Fig. 2). The predominant direction of groundwater flow was northwest (Fig. 2), thus it is unlikely that the initial drop in DOC concentrations observed at Well 3 were related to the increases in DOC concentrations at Well 2.

Groundwater samples collected from Well 2 showed a decrease in $\mathrm{NO}_{3}^{-}-\mathrm{N}$, increase in DOC and slight increase in $\mathrm{Cl}$ after the barrier was installed (Fig. 7). These data suggests that the barrier may be influencing groundwater quality as intended. Had the drop in $\mathrm{NO}_{3}{ }^{-} \mathrm{N}$ been due to dilution, we would have expected to see a decline in $\mathrm{Cl}$ concentrations in Well 2 (and possibly Well 3) samples, but that did not happen. Also, the environmental conditions were favorable for denitrification to occur in the barrier with average ORP, $\mathrm{DO}$ and temperature values of $-4 \mathrm{mV}, 2.7 \mathrm{mg} \mathrm{L}^{-1}$ and $19.8^{\circ} \mathrm{C}$, respectively in groundwater samples collected from Well 2 (Table 2). In reviewing the long term data and trends, there was a noticeable drop in average $\mathrm{NO}_{3}{ }^{-}$ $\mathrm{N}$ concentrations after the installation of the barrier (Fig. 8). Funding for this project would only allow for a few months of monitoring after the installation of the barrier and thus the results are preliminary. However a field study by Schipper and Vojvodic-Vukovic (2001) and a field and lab study by Robertson et al. (2008) both reported that PRBs could reduce groundwater $\mathrm{NO}_{3}{ }^{-} \mathrm{N}$ concentrations within a few months after installation and PRBs could continue to be effective for many years. Therefore, it is possible that the PRB installed in Martin County may help lower groundwater $\mathrm{NO}_{3}{ }^{-}-\mathrm{N}$ concentrations for decades.

Table 1. Average and standard deviation nitrogen, dissolved organic carbon and chloride concentrations for Wells 1-3 and pump tank effluent

\begin{tabular}{|c|c|c|c|c|c|}
\hline Location & $\mathrm{NH}_{4}{ }^{+}-\mathrm{N}(\mathrm{mg} / \mathrm{L})$ & $\mathrm{NO}_{3}{ }^{-}-\mathrm{N}(\mathrm{mg} / \mathrm{L})$ & TDN (mg/L) & $\mathrm{DOC}(\mathrm{mg} / \mathrm{L})$ & $\mathrm{Cl}(\mathrm{mg} / \mathrm{L})$ \\
\hline \multicolumn{6}{|l|}{ Average } \\
\hline Well 1 & 0.02 & 2.97 & 3.47 & 0.82 & 4.35 \\
\hline Well 2 & 0.02 & 13.98 & 14.23 & 20.37 & 14.67 \\
\hline Well 3 & 0.03 & 6.13 & 6.16 & 3.26 & 26.26 \\
\hline Pump Tank & 65.68 & 0.01 & 65.69 & 45.83 & 158.90 \\
\hline \multicolumn{6}{|c|}{ Standard Deviation } \\
\hline Well 1 & 0.01 & 1.01 & 0.14 & 0.17 & 0.08 \\
\hline Well 2 & 0.01 & 1.42 & 1.19 & 5.85 & 1.01 \\
\hline Well 3 & 0.01 & 0.09 & 0.09 & 3.98 & 1.40 \\
\hline Pump Tank & 3.58 & 0.01 & 3.58 & 14.16 & 10.33 \\
\hline
\end{tabular}

Table 2. Average and standard deviation environmental readings including depth to water, pH, Dissolved Oxygen (DO), temperature, Oxidation Reduction Potential (ORP) and Electrical Conductivity (EC)

\begin{tabular}{|c|c|c|c|c|c|c|}
\hline Location & Depth to water (m) & $\mathrm{pH}$ & $\mathrm{DO}(\mathrm{mg} / \mathrm{L})$ & Temp $\left({ }^{\circ} \mathrm{C}\right)$ & ORP $(\mathrm{mV})$ & $\mathrm{EC}(\mu \mathrm{S} / \mathrm{cm})$ \\
\hline \multicolumn{7}{|c|}{ Average Readings } \\
\hline Well 1 & 5.61 & 5.01 & 6.50 & 19.40 & 37 & 71 \\
\hline Well 2 & 6.34 & 4.99 & 2.70 & 19.80 & -4 & 244 \\
\hline Well 3 & 6.22 & 5.50 & 4.60 & 18.80 & 2 & 213 \\
\hline Pump tank & & 6.07 & 1.37 & 24.30 & -347 & 1475 \\
\hline \multicolumn{7}{|c|}{ Standard Deviation } \\
\hline Well 1 & 0.13 & 0.05 & 0.50 & 1.10 & 13 & 2 \\
\hline Well 2 & 0.10 & 0.33 & 0.70 & 1.30 & 34 & 4 \\
\hline Well 3 & 0.11 & 0.41 & 0.30 & 0.70 & 6 & 9 \\
\hline Pump tank & & 0.23 & 0.70 & 1.10 & 25 & 47 \\
\hline
\end{tabular}



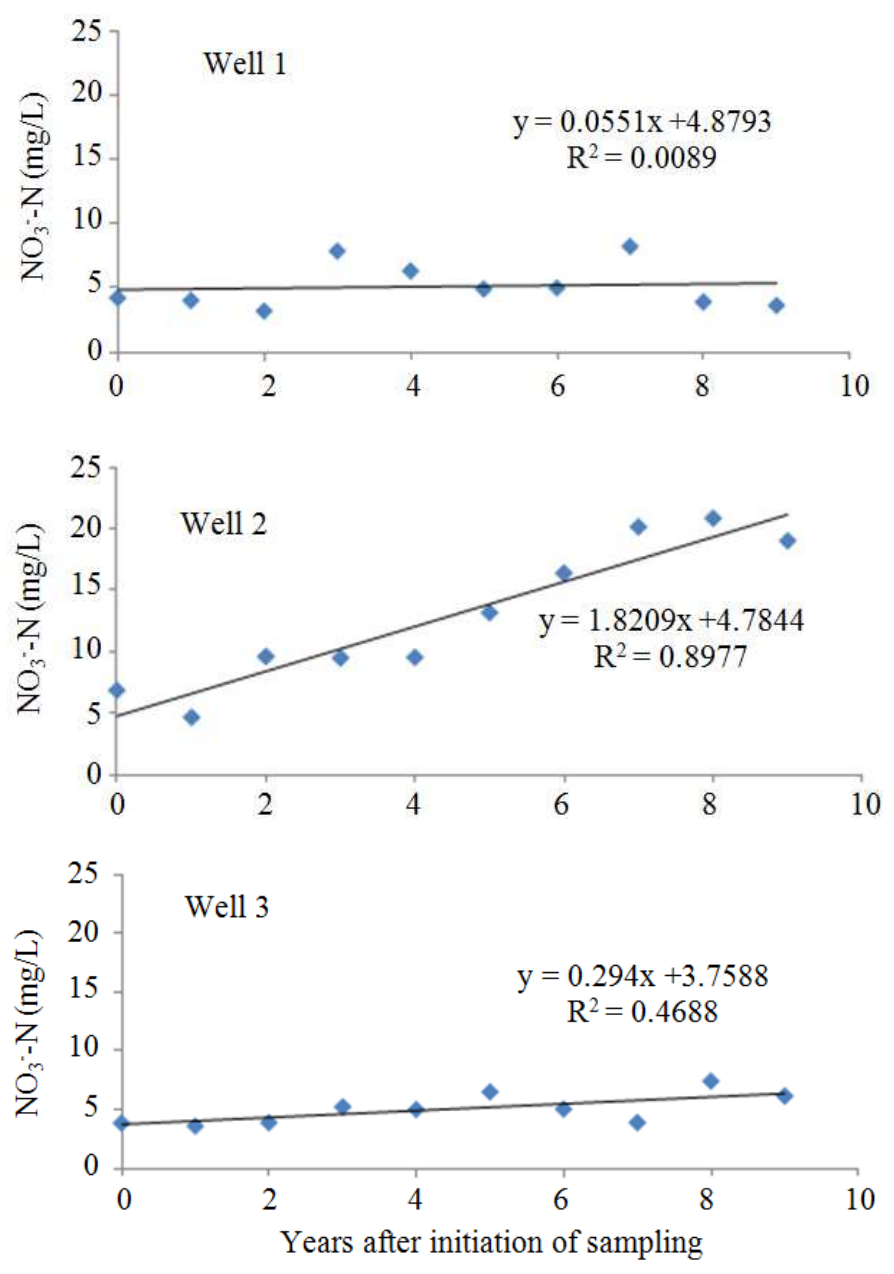

Fig. 5. Regression analysis of groundwater $\mathrm{NO}_{3}{ }^{-}-\mathrm{N}$ concentrations and years from initiation of sampling

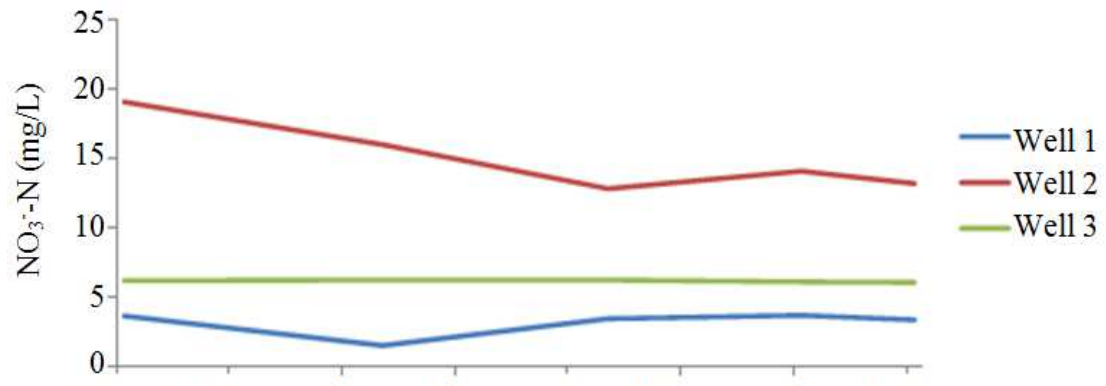

6-May 13-May 20-May 27-May 3-Jun. 10-Jun. 17-Jun. 24-Jun.

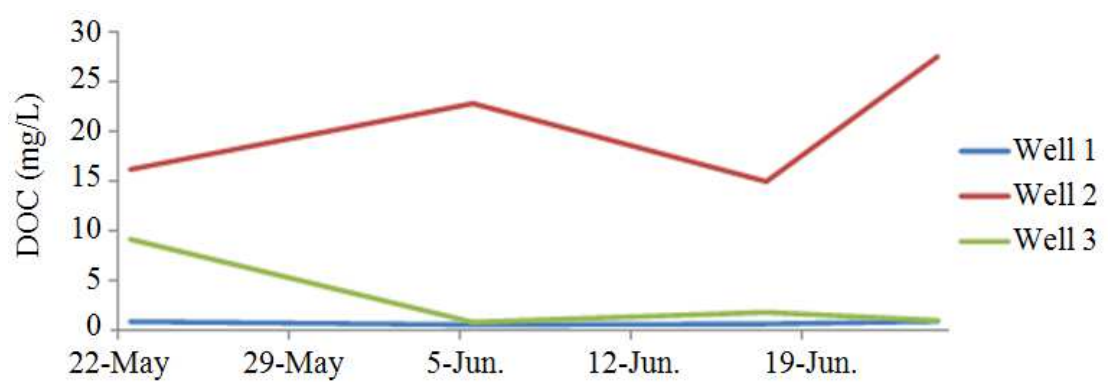




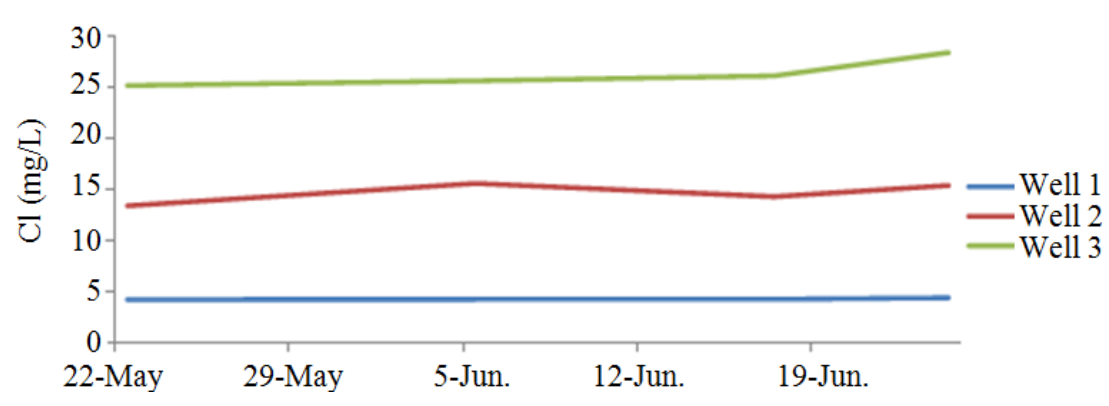

Fig. 6. Comparison of groundwater $\mathrm{NO}_{3}^{-}-\mathrm{N}, \mathrm{DOC}$ and $\mathrm{Cl}$ concentrations for Wells 1-3 before and after the barrier installation on May 7, 2014
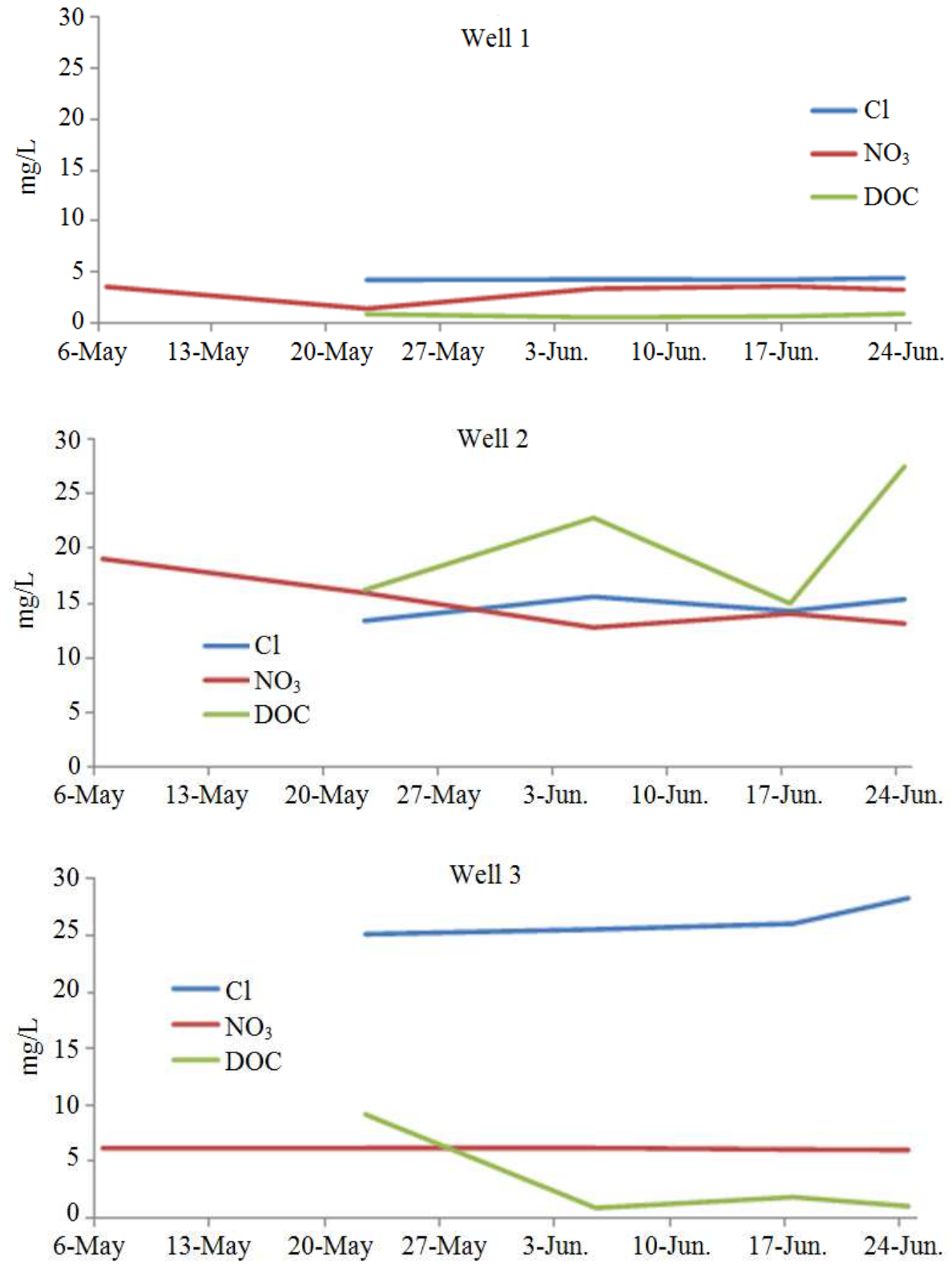

Fig. 7. Groundwater $\mathrm{Cl}, \mathrm{NO}_{3}{ }^{-}-\mathrm{N}$ and $\mathrm{DOC}$ dynamics for each well after the barrier installation on May 7, 2014 


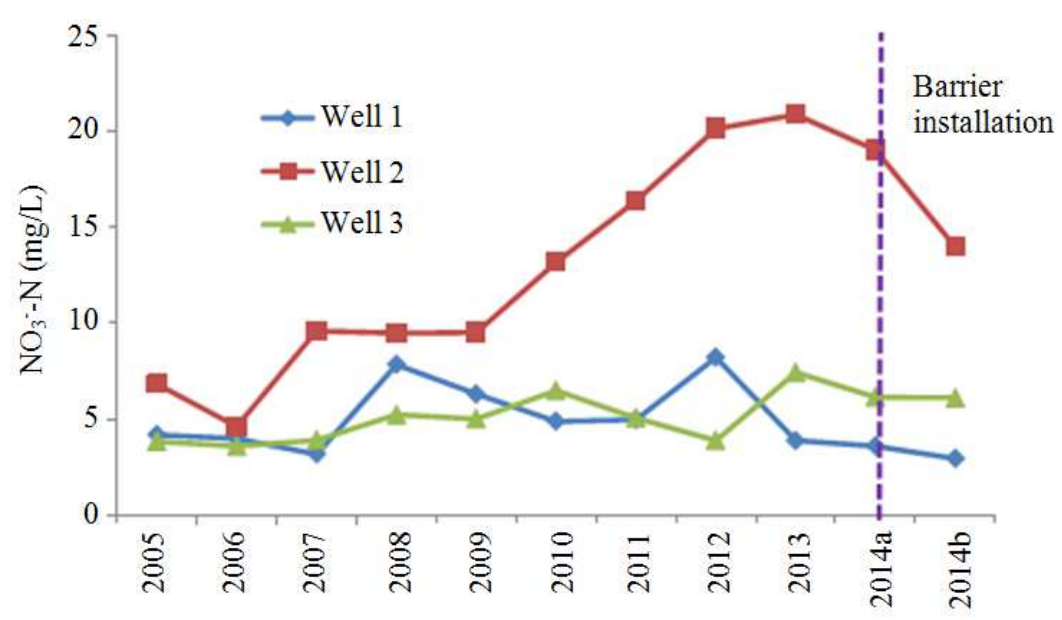

Fig. 8. Average annual groundwater $\mathrm{NO}_{3}{ }^{-} \mathrm{N}$ concentrations for wells 1-3 before the barrier installation (2005-2014a) and after the installation (2014b)

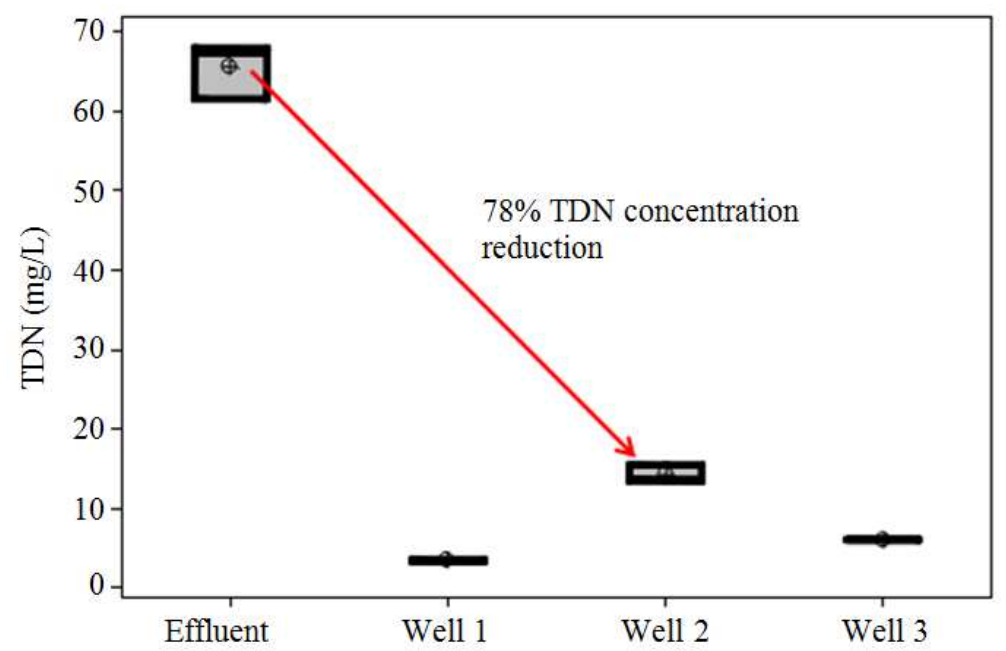

Fig. 9. Average Total Dissolved Nitrogen (TDN) concentrations for pump tank effluent and groundwater collected from wells 1-3

\section{Onsite System and Barrier Nitrogen Concentration Reduction Efficiency}

There was an average $\mathrm{TDN}\left(\mathrm{NO}_{3}^{-}-\mathrm{N}+\mathrm{NH}_{4}^{+}-\mathrm{N}+\right.$ Organic $\mathrm{N}$ ) concentration reduction of $78 \%$ from pump tank effluent $\left(65.7 \pm 3.6 \mathrm{mg} \mathrm{L}^{-1}\right)$ to groundwater at Well 2 (14.2 $\pm 1.2 \mathrm{mg} \mathrm{L}^{-1}$ ) after the barrier was installed (Fig. 9). Most of the groundwater TDN was $\mathrm{NO}_{3}^{-}-\mathrm{N}$ (Table 1) and thus there was opportunity for further reduction of groundwater $\mathrm{NO}_{3}{ }^{-} \mathrm{N}$ concentrations via denitrification, plant uptake and/or dilution in the riparian zone and creek bed over $152 \mathrm{~m}$ down-gradient from the OWS (Buetow, 2002; Osmond et al., 2002). Creek readings were performed on June 17, 2004 and June 24, 2004 with an YSI ProPlus meter and the $\mathrm{NO}_{3}{ }^{-}$ $\mathrm{N}$ concentration on both occasions was less than $1 \mathrm{mg}$ $\mathrm{L}^{-1}\left(0.65 \pm 0.35 \mathrm{mg} \mathrm{L}^{-1}\right)$.

\section{Environmental Readings}

Pump tank effluent had the highest average electrical conductivity $\left(1475 \pm 47 \mathrm{uS} \mathrm{cm}^{-1}\right), \mathrm{pH}(6.07 \pm 0.23)$ and temperature $\left(24.3 \pm 1.1^{\circ} \mathrm{C}\right)$ and lowest average DO $\left(1.37 \pm 0.7 \mathrm{mg} \mathrm{L}^{-1}\right)$ and ORP $(-347 \pm 25 \mathrm{mV})$ readings of all sampling locations (Table 2). Groundwater from Well 2 had the highest average groundwater EC $(244 \pm 4 \mathrm{uS}$ $\left.\mathrm{cm}^{-1}\right)$ and temperature $\left(19.8 \pm 1.3^{\circ} \mathrm{C}\right)$ and lowest average DO $\left(2.7 \pm 0.7 \mathrm{mg} \mathrm{L}^{-1}\right)$ and ORP $(-4 \pm 34 \mathrm{mV})$ readings (Table 2). These data indicated that groundwater physical and chemical properties at Well 2 were influenced the most by the OWS. Groundwater at Well 3 had the highest average $\mathrm{pH}(5.5 \pm 0.41)$, intermediate average EC $\left(213 \pm 9 \mathrm{uS} \mathrm{cm}{ }^{-1}\right)$, ORP $(2 \pm 6 \mathrm{mV})$ and DO $\left(4.6 \pm 0.3 \mathrm{mg} \mathrm{L}^{-1}\right)$ readings. Groundwater near Well $1 \mathrm{had}$ the highest DO $\left(6.5 \pm 0.5 \mathrm{mg} \mathrm{L}^{-1}\right)$ and ORP $(37 \pm 13 \mathrm{mV})$ 
and lowest average groundwater EC $\left(71 \pm 2 \mathrm{uS} \mathrm{cm}^{-1}\right)$. These data indicate that Well 3 may also have been influenced by the OWS, but Well 1 was least affected. This was expected because Well 1 is located up-gradient from the OWS drainfield and Wells 2 and 3 are located down-gradient from the OWS.

\section{Conclusion}

Groundwater $\mathrm{NO}_{3}^{-}-\mathrm{N}$ concentrations steadily increased by $1.8 \mathrm{mg} \mathrm{L}^{-1}$ each year since 2006 near Well 2 at the study site prior to the installation of the barrier. Groundwater samples (5) from Well 2 collected 2 weeks to 4 months after the installation were on average $5 \mathrm{mg}$ $\mathrm{L}^{-1}$ lower than samples collected the day prior to the installation. Groundwater DOC increased by more than $11 \mathrm{mg} \mathrm{L}^{-1}$ and $\mathrm{Cl}$ concentrations increased almost $2 \mathrm{mg}$ $\mathrm{L}^{-1}$ over the same period. These data suggest that the $\mathrm{NO}_{3}{ }^{-}-\mathrm{N}$ reductions were not due to dilution alone. It should be noted that while groundwater $\mathrm{NO}_{3}{ }^{-} \mathrm{N}$ concentrations have exceeded the $10 \mathrm{mg} \mathrm{L}^{-1}$ drinking water standard at Well 2, community water has been extended to the area near the study site. The public water supply is routinely tested for contaminants to protect public health. Also, most water supply wells are not installed in the surficial aquifer, but deeper, confined aquifers that may not be very well connected to the surficial unit (Stone et al., 1995; Humphrey et al., 2013). Therefore, elevated $\mathrm{NO}_{3}^{-}-\mathrm{N}$ concentrations in the surficial aquifer may not have a significant influence on groundwater in deeper aquifers (used for water supply). There is great potential for denitrification in the riparian area and creek bed to limit OWS plume $\mathrm{NO}_{3}{ }^{-} \mathrm{N}$ loading to the creek. Because the creek is located over $152 \mathrm{~m}$ from the OWS, there is also opportunity for dilution and dispersion to lower $\mathrm{NO}_{3}{ }^{-}-\mathrm{N}$ concentrations as groundwater approaches the stream. The creek had less than $1 \mathrm{mg} / \mathrm{L} \mathrm{NO}_{3}{ }^{-} \mathrm{N}$ on both dates it was tested.

Groundwater residence times from the OWS to the stream are not known at this time. With additional funding a more comprehensive investigation could be completed. Installing at least one monitoring well for sample collection and analysis up-gradient and at least one well within the barrier would be beneficial for quantifying the $\mathrm{NO}_{3}{ }^{-}-\mathrm{N}$ treatment efficiency of the barrier. The $\mathrm{NO}_{3}{ }^{-} \mathrm{N}$ concentrations and $\mathrm{NO}_{3}{ }^{-}-\mathrm{N}$ to $\mathrm{Cl}$ ratios up-gradient, within the barrier and down-gradient (Well 2) over time could be analyzed to provide a more definitive answer as to the effectiveness of the barrier. Cost-effectiveness of these systems may be related to the water table and plume depth. In the North Carolina Coastal Plain, shallow ( $<5 \mathrm{~m}$ depth) water tables are common and recent groundwater depth models by Fan et al. (2013) may help to screen areas where water table depth is suitable for PRBs.

There is a lack of field based research comparing the efficiency of barriers in remediating $\mathrm{NO}_{3}{ }^{-} \mathrm{N}$ and other contaminants in different geologic settings and with various mixtures of reactive materials. More work is suggested in these research areas.

\section{Acknowledgement}

The authors would like to thank the Martin County, NC school maintenance personnel for all the extra effort they provided towards this project. The authors would like to acknowledge the NC Department of Health and Human Services for funding the study and graduate student Sarah Hardison for assistance with some of the fieldwork.

\section{Author's Contributions}

Each author contributed to the preparation and development of this manuscript.

\section{Ethics}

The authors are unaware of any ethical issues that would arise related to the publication of this manuscript.

\section{References}

Bowen, J.L. and I. Valiela, 2004. Nitrogen loads to estuaries: Using loading models to assess the effectiveness of management options to restore estuarine water quality. Coastal Estuarine Res. Federat., 27: 482-500. DOI: 10.1007/BF02803540

Brady, N.C. and R.R. Weil, 2003. Elements of the Nature and Properties of Soils. 1st Edn., Prentice Hall, ISBN-10: 013048038X, pp: 624.

Buetow, W.S., 2002. On-site wastewater nitrogen contributions to a shallow aquifer and adjacent stream. North Carolina State University.

Cardona, M.E., 2006. Nutrient and pathogen contributions to surface and subsurface waters from on-site wastewater systems-a review. North Carolina Department of Environment and Natural Resources.

Del Rosario, K.L., C.P. Humphrey, S. Mitra and M. O'Driscoll, 2014. Nitrogen and carbon dynamics beneath on-site wastewater treatment systems in Pitt County, North Carolina. J. Water Sci. Technol., 69: 663-671. DOI: 10.2166/wst.2013.765

Desimone, L.A. and B.L. Howes, 2006. Denitrification and nitrogen transport in a coastal aquifer receiving wastewater discharge. Environ. Sci. Techno., 30: 1152-1162. DOI: 10.1021/es950366p 
Harman, J., W.D. Robertson, J.A. Cherry and L. Zanini, 1996. Impacts on a sand aquifer from an old septic system: Nitrate and Phosphate. Ground Water, 34: 1105-1114. DOI: 10.1111/j.1745-6584.1996.tb02177.x

Fan, Y., H. Li and M. Miguez-Macho, 2013. Global patterns of groundwater table depth. Science, 339: 940-943.

Humphrey, C.P., M.A. O'Driscoll and M.A. Zarate, 2010. Controls on groundwater nitrogen contributions from on-site wastewater systems in Coastal North Carolina. J. Water Sci. Technol., 62: 1448-55. DOI: $10.2166 /$ wst.2010.417

Humphrey, C.P., M.A. O’Driscoll, N. Deal, D. Lindbo and M.A. Zarate-Bermudez et al., 2013. On-site wastewater system nitrogen contributions to groundwater in coastal North Carolina. J. Environ. Health, 76: 16-22.

Long, L.M., L.A. Schipper and D.A. Bruesewitz, 2011. Long-term nitrate removal in a denitrification wall. Agric. Ecosyst. Environ., 140: 514-520. DOI: $10.1016 /$ j.agee.2011.02.005

Lowe, K.S., N.K. Rothe, J.M.B. Tomaras, K. DeJong and M.B. Tucholke et al., 2007. Influent constituent characteristics of the modern waste stream from single sources: Literature review. Water Environment Research Foundation, Alexandria, VA, USA.

NOAA, 1996. NOAA's estuarine eutrophication survey. South Atlantic Region, Office of Ocean Resources Conservation Assessment, National Oceanic and Atmospheric Administration, Silver Spring, MD, USA.

O'Driscoll, M.A., C.P. Humphrey Jr, N.E. Deal, D.L. Lindbo and M.A. Zarate-Bermudez, 2014. Meteorological influences on nitrogen dynamics of a coastal onsite wastewater treatment system. J. Environ. Q., 43: 1873-85. DOI: $10.2134 /$ jeq2014.05.0227

Osmond, D.L., J.W. Gilliam and R.O. Evans, 2002. Riparian Buffers and Controlled Drainage to Reduce Agricultural Nonpoint Source Pollution. North Carolina Agricultural Research Service Technical Bulletin 318, North Carolina State University, Raleigh, NC.

Osmond, D.L., S.H. Hodges, D.H. Hardy, W. Lord and H.J. Kleiss et al., 2003. Tar-Pamlico River basin nutrient management education. North Carolina Cooperative Extension Service, North Carolina State University. Raleigh, NC.

Postma, F.B., A.J. Gold and G.W. Loomis, 1992. Nutrient and microbial movement from seasonallyused septic systems. J. Environ. Health, 55: 5-10.
PASS, 2015. Permeable reactive barrier illustration information. Powell and Associates Science Services.

Pradhan, S.S., M.T. Hoover, R.E. Austin and H. Devine, 2007. Potential nitrogen contributions from on-site wastewatertreatment systems to North Carolina's River Basins and Subbasins. North Carolina Agricultural Research Service Technical Bulletin 324, Raleigh, NC, USA

Ptacek, C.J., 1998. Geochemistry of a septic-system plume in a coastal barrier bar, Point Pelee, Ontario, Canada. J. Contaminant Hydrol., 33: 293-312. DOI: $10.1016 / \mathrm{S} 0169-7722(98) 00076-\mathrm{X}$

Reay, W.G., 2004. Septic tank impacts on ground water quality and Nearshore sediment nutrient flux. Groundwater, 42: 1079-1089. DOI: 10.1111/j.1745-6584.2004.tb02645.x

Robertson, W.D., J.A. Cherry and E.A. Sudicky, 1991. Ground-water contamination from two small septic systems on sand aquifers. Ground Water, 29: 82-92. DOI: 10.1111/j.1745-6584.1991.tb00500.x

Roberson, W.D. and J.A. Cherry, 1995. In situ denitrification of septic-system nitrate using reactive porous media barriers: Field trials. Groundwater, 33: 99-111. DOI: 10.1111/j.1745-6584.1995.tb00266.x

Robertson, W.D., J.L. Vogan and P.S. Lombardo, 2008. Nitrate removal rates in a 15 -year-old permeable reactive barrier treating septic system nitrate. Groundwater Monitor. Remediat., 28: 65-72. DOI: 10.1111/j.1745-6592.2008.00205.x

Schipper, L.A. and M. Vojvodic-Vukovic, 2001. Five years of nitrate removal, denitrification and carbon dynamics in a denitrification wall. Water Res., 35: 3473-3477. DOI: 10.1016/S0043-1354(01)00052-5

Stone, K.C., J.M. Novak, G.D. Jennings, R.A. McLaughlin and P.G. Hunt, 1995. Groundwater quality in an eastern coastal plain watershed. Proceedings of the Clean Water Clean Environment 21st Century Conference (CC'95), pp: 263-266.

USEPA, 2002. On-site wastewater treatment systems manual. EPA/625/R-00/008. United States Environmental Protection Agency. 2003. Bacterial Water Quality Standards for Recreational Waters (Freshwater and Marine waters) Status Report. EPA/823/R/03/008. 